\title{
Botany
}

\section{Preliminary assessment of the conservation status of medicinal plant species in Canada}

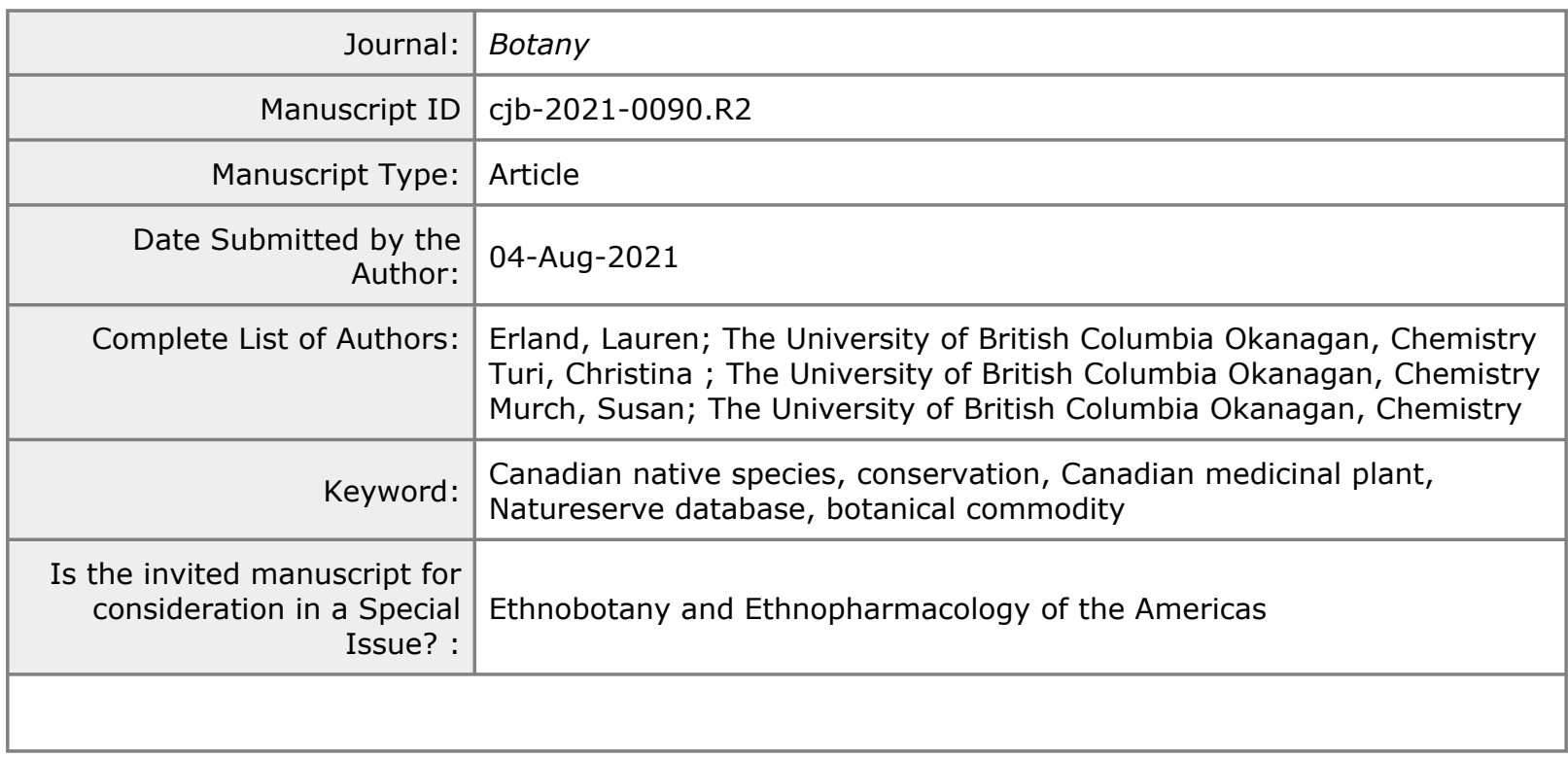

\section{SCHOLARONE" Manuscripts}


1 Preliminary assessment of the conservation status of medicinal plant species in Canada

2

3 Lauren A E Erland ${ }^{1}$, Christina E Turi ${ }^{1}$, Susan J Murch ${ }^{1 *}$

4

$5 \quad{ }^{1}$ Chemistry, University of British Columbia, Kelowna, BC, Canada

6

$7 \quad *$ Corresponding Author, susan.murch@ubc.ca

8 
9 Abstract

11 Natural health products in North America are a 9.6 billion US dollar industry that has seen

12 increased demands particularly in products for immune support and anti-viral supplements in

13 response to the Covid-19 pandemic. It has been estimated that $\approx 40 \%$ of the plant raw materials

14 used in natural health products are wild-harvested each year but exact data is missing for many

15 species. Our data show that there are at least 1445 medicinal plant species harvested for

16 commercial products in Canada and 1217 of these are native species. Medicinal plants and non-

17 timber forest crops are also increasingly impacted by climate change as suitable growing areas

18 migrate. In order to ensure long term species survival in the wild, it is necessary to generate

19 accurate information about distribution of wild populations, need for conservation and

20 sustainable method development. Our objective was to provide a preliminary assessment on the

21 conservation status of Canadian medicinal plants by analysis of the available data resources.

24 Keywords

25 Canadian medicinal plant, Canadian native species, conservation, Natureserve database, 26 botanical commodities 


\section{Introduction}

29 Medicinal plants are used widely both as traditional medicines and natural health products.

30 Consumption of natural health products in North America represents a 9.6 billion US dollar

31 industry, which increased by $8.6 \%$ in 2019 and has seen a significant spike in value in 2020 as

32 people search for immune boosting and alternate medicines in the face of the COVID-19

33 pandemic (Smith et al. 2020). Many native North American species including: elderberry

34 (Sambucus nigra L. and Sambucus canadensis L.; \$107.5M USD), echinacea (Echinacea spp.;

35 \$120.1M USD), cranberry (Vaccinium macrocarpon L.; \$88.9M USD), and black cohosh

36 (Actaea racemosa L; \$28.1M USD) contribute significantly to this value (Smith et al. 2020).

37 While the American Herbal Product Association (AHPA) 2020 tonnage report reports wild and

38 cultivated harvest values for 40 botanical commodities, no such resource is available for the

39 Canadian natural health product industry, leaving the impacts of wild harvest unknown in

40 Canada (AHPA 2020).

42 Canada is experiencing climate change at rates of two to four times the global average and

43 northern ecosystems are expected to bear the brunt of the harshest changes (Government of

44 Canada 2019). Globally it has been estimated that as high as $27 \%$ of plant species red listed by

45 the International Union for the Conservation of Nature (IUCN) species are threatened, with $2.2 \%$

46 of the 91 Canadian species assessed in the study having being identified as threatened (Brummitt

47 et al. 2015). The species at risk act (SARA) lists three extirpated, 45 endangered and 42 special

48 concern plant species (SARA, 2021). It has been estimated that Canada is home to more than

495,000 vascular and more than 1,000 non-vascular plant species, with only $74 \%$ of Canada's 
50 native plant species have been assessed for conservation status overall (Canadian Endangered

51 Species Conservation Council, 2016).

53 Cultivating commercially important medicinal species is one way to ensure that species are not

54 overharvested, and wild populations are secure but these methods are not available for all

55 species. In particular, the following species may be at risk due to overharvest for commercial

56 products: bloodroot (Sanguinaria canadensis L.), American ginseng (Panax quinquefolis L.),

57 black cohosh (Actaea racemosa L. ), blue cohosh (Caulophyllum thalictroides (L.) Michx),

58 eyebright (Euphrasia spp.), false unicorn root (Chamaelirium luteum(L.) A.Gray), goldenseal

59 (Hydrastis canadensis L.), lady’s slipper orchid (Cypripedium spp.), Lomatium spp., osha

60 (Ligusticum spp.), slippery elm (Ulmus rubra Muhl.), bethroot (Trillium sp.), true unicorn root

61 (Aletris farinosa L.), virginia snakeroot (Aristolochia serpentaria L.), and wild yam (Dioscorea

62 spp.)(COSEWIC 2021; UPS 2021). Recent increases in commercial demand for products made

63 from some native Canadian species such as black huckleberry (Vaccinium membranaceum

64 Douglas ex Torr), Labrador tea (Rhododendron groenlandicum (Oeder Kron \& Judd), and Arctic

65 willows (Salix arctica Pall.) may pose risks to wild populations that have yet to be investigated.

66 The objective of the current study was to collate the available data on Canadian medicinal plant

67 diversity, commercial use, and conservation status to identify knowledge gaps and areas of

68 potential concern. We assessed Canadian records in the Natureserve database, the AHPA Herbs

69 of Commerce, Moerman's Ethnobotanical database and the available Conservation Data Centers

70 (CDCs). These data provide a preliminary glimpse of medicinal plant diversity and use in

71 Canada and provide recommendations for areas in need of further study. 
Medicinal Plants Classification

76 Two selected datasets were generated from the available databases: Dataset \#1 - A

77 comprehensive list of known medicinal taxa in Canada (Supplementary Table 1) and Dataset \#2 -

78 Canadian medicinal plant species listed in the AHPA Herbs of Commerce (HoC; Supplementary

79 Table 2). The comprehensive list of all known Canadian medicinal taxa (2703 total) were

80 acquired from the Native American Ethnobotany Database (http://herb.umd.umich.edu/) in Fall

81 2016. The database contains ethnobotanical information for at least 3618 plant species with

82 reported uses by 291 First Nations with territories north of the Mexican border in North America

83 (Moerman 2009). The AHPA HoC is a listing of standardized common and scientific names for

84 commercially utilized species (McGuffin et al. 2001). Species presence was then assessed as

85 native or invasive using the United States Department of Agriculture (USDA) "PLANTS

86 Database" (https://plants.usda.gov/java/) and applying a custom-built macro in Excel, and only

87 native species were retained for further analysis.

89 Conservation Rankings

90 Conservation rankings and distribution were acquired by visiting the NatureServe explorer

91 database (http://explorer.natureserve.org/index.htm) in Fall of 2016 and again in Winter 2021

92 with distribution sorted by the subnational regions. Natureserve rankings are designated as G -

93 global, $\mathrm{N}$ - national and $\mathrm{S}$ - subnational (province, territory or region in the case of Labrador),

94 and the conservation status designated numerically as 1 - Critically Imperiled, 2 - Imperiled, 3 -

95 Vulnerable, 4 - Apparently Secure, 5 - Secure, NA - Not Applicable, NR - Unranked, X- 
96 Presumed Extirpated, H - Possibly Extirpated and U - Unrankable. Additional subnational

97 rankings were acquired from targeted Natureserve CDCs for three selected regions of special

98 interest: British Columbia (BC) which has the greatest number of medicinal species unique to

99 BC (BCCDC; http://a100.gov.bc.ca/pub.eswp; Supplementary Table 3), Nunavut where the

100 minority of flora has been assessed (no territorial CDC data available, Natureserve Explorer data

101 used; Supplementary Table 4) and the Northwest Territories where a majority of species have

102 been assessed (NWT Species Infobase www.enr.gov.nt/ca/species-search; Supplementary Table

103 5). In all cases queries were for "All" and "Plants OR Plantae". These lists were then cross

104 referenced with list 1 matching by element code and only medicinal species were retained.

105 Committee for the Status of Endangered Wildlife in Canada (COSEWIC) and SARA listing

106 status was extracted from Natureserve Explorer and the respective CDCs where applicable.

108 Data Analysis

109 Once working datasets were compiled, logical algorithms were applied in Excel to identify

110 specific trends and patterns in the dataset with respect to medicinal plant distribution,

111 conservation status, and year assessed. Where conservation status was a composite e.g. S1S2,

112 both ranks were counted. Data were plotted in QGIS (v 3.10) and Prism 9 (GraphPad, USA).

113 Overrepresentation analysis was performed using linear regression and residual analysis as

114 described by Turi and Murch 2013 for Natureserve national rankings and SARA listings. Data

115 were downloaded for all species which were designated as present in Canada AND Native from

116 Natureserve Explorer by national rank (excluding not applicable ranking) in July 2021 and

117 combined into a single dataset. A total of 271 plant families were found to be present but only

118136 families had at least 1 medicinal species present and were retained for further analysis. 
119 Taxonomy was resolved and plant family assigned using TNRS: Taxonomic Name Resolution

120 Service (v5.0)(Boyle et al. 2013). To investigate whether particular plant families could be

121 considered at greater or lesser risk we performed overrepresentation and residual analysis of the

122 number of medicinal species in each family present at each national ranking level (e.g. N1-N5,

$123 \mathrm{NR}, \mathrm{NX}, \mathrm{NU}, \mathrm{NH}$ and SARA listing). The total number of all native Canadian species by family

124 was assigned as the independent variable and total number of native Canadian medicinal species

125 by family as the dependent variable and the equation of the line of best fit was determined.

126 Residuals were determined by calculating the expected number of species in each rank

127 classification (Natureserve national ranks or SARA listing) using the equation of the line of best

128 fit and the equation of the line of best fit forcing an intercept of $(0,0)$ and subtracting expected

129 from observed number of species at each rank level.

$131 \quad$ Results

National (Canadian) conservation ranking of Canadian medicinal plant species

134 Canada is home to at least 1,446 medicinal plants species with 1,220 of them assessed to

135 be native to Canada. Our analysis found that at least $28 \%$ of Canada's vascular flora is

136 medicinal. The greatest number of medicinal species are located in Ontario with 1042 species

137 (Figure 1a) of which 807 (Figure 1b) are considered to be native, and of these 90 were present

138 only in Ontario (Figure 2). BC had the greatest number of medicinal species unique to the

139 province, of 882 total medicinal species (Figure 1a) 704 are considered native (Figure 1b) and

140141 are unique to the province (Figure 2). 54\% of Canadian medicinal plants have been assessed

141 to be secure (Figure 1c, Figure 2), in comparison with only $42 \%$ of all Canadian species (Figure 
142 1d) while $15 \%$ are either possibly extirpated, critically imperiled, imperiled or vulnerable (Figure

143 1c), compared to $23 \%$ of all Canadian species classified similarly (Figure 1d). species, identified that $92 \%$ of all Canadian medicinal plants have been allocated a national

147 conservation status over the last 10 years, with 586 being assigned or having updated rankings in 1482016 (Figure 3). Assessing the Canadian species which are currently deposited at the Millenium 149 Seedbank at Kew, United Kingdom, of the total 1,446 total Canadian medicinal species (native 150 and non-native), only about $10 \%(n=120)$ have been deposited.

To determine if the proportions of native Canadian medicinal species by rank was

152 reflective of the general proportion of native Canadian flora more generally, a residual analysis 153 was performed. Both the line of best fit and the line of best fit forcing an intercept of $(0,0)$, as a 154 negative number of predicted species was not possible, showed similar trends (Table 1). Native 155 Canadian medicinal species were found to be overrepresented only in the secure (N5) rank, and 156 underrepresented in N2, N3, N4 and NNR (Table 1). Examination of native Canadian medicinal 157 species by family as compared to overall composition of Canadian flora for species listed as N1 158 or $\mathrm{N} 2$ found that the Asteraceae and Fabaceae were both overrepresented in the imperiled (N2) 159 to critically imperiled rank (N1) while the Cyperaceae and Poaceae were both underrepresented 160 (Figure 4). A similar trend was also observed upon examination of SARA-listed species with the 161 Fabaceae, Asteraceae, Gentianceae and Asparagaceae all being overrepresented and the 162 Orchidaecae, Cyperaceae and Orobanchaceae all being underrepresented in the SARA listing for 163 native Canadian medicinal species as compared to all Canadian flora (Figure 5, Table 2). 


\section{Subnational conservation ranking of Canadian medicinal plant species.}

Native Canadian medicinal species were assessed at the subnational level. Our analysis identified Saskatchewan as having the highest number of S1 ranked native Canadian medicinal species (9.8\%), followed by Prince Edward Island (9.3\%), Nova Scotia (8.1\%) and Yukon (7.8\%; Figure 6). The number of native Canadian medicinal species assessed by Natureserve varied by province. Nunavut had the lowest percent of medicinal species with $84 \%$ not yet assessed (SNA, SNR, SU) while the Northwest Territories (NWT) has the lowest proportion of species yet to be assessed at only $11.2 \%$ (Figure 3b, Figure 6). A review of the native Canadian species unique to each province at the subnational level found that while $35 \%$ of these species were secure (S5), 39\% were at risk or imperiled (S1 or S1S2) with $3 \%$ already considered extirpated (Figure 2 inset). We additionally examined how many of the 27 native Canadian medicinal species unique to a single province and ranked as S1 or S1S2 have been listed by

SARA/COSEWIC and found only 16 or $59 \%$ of those species considered most at-risk by the Natureserve Ranking are similarly listed by SARA (Table 3). Breaking this information down by province shows that the number of S1 or S1S2 listed unique native Canadian medicinal species by province roughly match the proportions of total medicinal species by province with Ontario (72\%) then BC (15\%) being most represented followed by Alberta (8\%) and Manitoba and Nova Scotia (3\% each; Table 3, Figure 2). Expanding the criteria to include all native Canadian medicinal species with a critically imperiled or imperiled ranking ( $\mathrm{S} 1$ or S2, respectively), and unique to a single province identified 70 species from 34 plant families, less than half of these species have been assessed by SARA/COSEWIC (32/70).

Nine species were identified which are unique to a single province and have not been assessed (SNR or SU) - 5 in Ontario and 4 in BC; 5 of these species additionally lack a ranking 
188 in the US (Table 4). Cross referencing of the Natureserve explorer data to BCCDC identified 189 one, Asauram caudatum Lindl., for which an assessment has been performed and included in the 190 BCCDC database but for which the subnational ranking has not been updated in Natureserve 191 Explorer and one species, Solidago speciosa Nutt., having been assessed by SARA (Table 4).

192 The pattern of species distribution by family is similar to that at the national level with the

193 Rosaceae being most common in this list $(n=3)$ followed by the Asteraceae $(n=2)$, Apiaceae $194(\mathrm{n}=1)$, Aristolochiaceae $(\mathrm{n}=1)$, Solanaceae $(\mathrm{n}=1)$, and Viscaceae $(\mathrm{n}=1)$ also represented. A closer examination of NWT, which has the greatest percent of species assessed,

197 Nunavut, with the lowest proportion assessed, and BC, which has the greatest number of unique 198 species, found several unique trends. The BCCDC lists 3,500 species which meet the criteria of 199 "Native" AND "Plants", and of these 432 are also present in List 1. A total of 1,245 plant species 200 are reported in the NWT Infobase with 274 also present in List 1. No species at risk are 201 identified in either NWT or Nunavut by COSEWIC or SARA, while $96 \%$ of BC plant species 202 have not been assessed, of the 4 that have been assessed $2.7 \%$ are threatened, endangered or of 203 special concern. Both BC and NWT use Natureserve subnational rankings to assign 204 provincial/territorial conservation rankings. While neither of the territories have any species 205 listed as critically imperiled (S1), 18\% of species in the NWT and more than half of all species 206 assessed in Nunavut (12.5\% of the $22 \%$ assessed) are ranked as imperiled or vulnerable, in 207 contrast BC has $2 \%$ of species listed as S1, $0.67 \%$ are presumed or possibly extirpated, and $9.5 \%$ 208 are imperiled or vulnerable (Figure 7). 
211 major reassessment of BC species status was performed in 2019 with $37 \%$ of species receiving a

212 revised status, while $96 \%$ of NWT species were reassessed in 2015 or later. A similar effort

213 assessment effort is still needed for Nunavut.

215 Medicinal species of commercial value

216 To evaluate the assessment status of commercially traded medicinal species, species

217 included in the AHPA HoC were assessed for their global and national rankings; 373 HoC are

218 reported to occur in North America, of which $40 \%$ of these have not been assessed in

219 Natureserve (GNR, GNA or GU; Figure 8a). None of the HoC species included in this analysis

220 were ranked globally at the G2 (Imperilled) level or higher, though $2.5 \%$ are considered globally

221 vulnerable (Figure 8a). In Canada, $238 \mathrm{HoC}$ are reported to be present, with 29 present in a

222 single province. Less than half of all the HoC species which are present in Canada are, however,

223 native (111) but a higher proportion (19/111) of native species list as an HoC are present in a

224 single province (Table 5). Seven species were found to be SARA listed among the AHPA HoC

225 species and of these four are both unique to a single province and are listed as of special concern

226 or endangered (Table 6). These include commonly recognized species such as Panax cinquefolis

227 and Hydrastis canadensis. The most represented families in the AHPA HoC list differ from the

228 overall distribution of medicinal species assessed to this point with the Lamiaceae being most

229 represented followed by the Apiaceae, Asteraceae and Paeonianeae (Figure 8d). The provinces

230 with the greatest number of AHPA HoC species in descending order are Ontario (66\%), BC (24

$231 \%$, Nova Scotia, Prince Edward Island (PEI) and Quebec (3.5\% each; Figure 8c). Our query of

232 the Natureserve database found that $38 \%$ of species included in the AHPA HoC are ranked as 
233 Critically Imperiled, Imperiled or Vulnerable at the subnational level while 35\% are non-native

234 (SNA) or have not been assessed (Figure 8b).

236 Discussion

As global climates continue to shift and demand for plant and plant-derived natural health products continues to grow, a centralized Canadian system which can be publicly accessed and

240 which gathers together ethnobotanical, distribution and conservation data will be key in

241 developing future conservation priorities including determination of sustainable harvest levels

242 and listing of species. It should also be noted that while general distribution data is of significant

243 value, the exact locations of data should not be publicized to minimize risk of poaching either of

244 species which are already at risk or which may become at risk should over harvest occur. We

245 integrated ethnobotanical, spatial distribution and conservation ranking data to assess the current

246 conservation status of Canadian medicinal plant species. We identified more than 1,446

247 medicinal species known to grow in Canada, of which 882 are native. Our analysis has

248 highlighted several key themes in both the strengths and the gaps of medicinal plant conservation

249 data in Canada and identified several key groups of species which should be prioritized for

250 further assessment.

251 Medicinal plants were overall found to be assessed at similar rates to those observed for

252 the whole flora of Canada, and to generally be overrepresented as compared to Canada native

253 flora overall in the secure designation. Our analysis, however, found that this was not universally

254 true across plant families. Several families were identified which should be considered as

255 priorities for conservation, namely those which are overrepresented in the N1, N2 and SARA 
256 listed designations, especially the Fabaceae and Asteraceae. The Lamiaceae are also highly

257 represented in the AHPA HoC species, and as these species are included on this list due to their

258 commercial importance, these species should also be further considered as they may be more

259 likely to experience commercial harvest pressure in addition to common pressures such as loss of

260 habitat or degradation of the existing habitat through climate change or human activity. While

261 the sustainability of medicinal plant harvest is an active area of consideration in the United

262 States, for example with the establishment of sustainability initiatives through organizations such

263 as AHPA (AHPA 2018), less attention has been paid to Canadian medicinal species and

264 populations (Oliver and Leaman 2018).

A significant gap in the knowledge of the conservation status of Canadian medicinal

267 plants is the lack of data for Nunavut (Government of Canada 2019). Overall 15\% of Canadian

268 medicinal species have not been assessed with the number of medicinal species yet to be

269 assessed being roughly proportional to that of native Canadian plants more broadly. While most

270 subnational regions have about $60-90 \%$ of medicinal species which have been assessed, in

271 comparison only about $10 \%$ of Nunavut species have been assessed. This is particularly

272 concerning as Nunavut, and Inuit Nunangat are experiencing climate change at up to four times

273 the global average rate, making these species a potentially particularly vulnerable subset of

274 Canadian medicinal plant diversity and an understanding of the current status of species in this

275 environment of particular concern (Government of Canada 2019). Mapping of Nunavut flora

276 comes with unique challenges inherent to the geography of the region; Nunavut is Canada's

277 largest territory comprising $5 \%$ of Canada's overall landmass with most communities and

278 regions accessible only by air. Integration of data systems into a national framework, along with 
279 integration of ethnobotanical and Traditional Ecological Knowledge (TEK) surrounding these

280 plants, would further help to develop this framework. Many Nunavut species are common across

281 the NWT, Nunavut and Northern Quebec, a geopolitical region which comprises Inuit Nunangat

282 (the Inuit Homeland). Efforts in collaboration among scientists, Inuit elders and community

283 members in these regions have also generated significant knowledge including traditional

284 medicine and TEK. For example, native berries such as crowberry/blackberry (Empetrum nigrum

285 L.), blueberry (Vaccinium uliginosum L.), mountain

286 cranberry/lingonberry/partridgeberry/redberry (Vaccinium vitis-idaea L.), marshberry/small

287 cranberry (Vaccinium oxycoccus L.), bearberries (Arctous alpina L. Nied. and A. rubra Rehder \&

288 Wilon Nakai, syn Arctostaphylos spp.) and cloudberries (Rubus chaemaemorus L.) represent

289 cultural, medicinal and food species which are all well documented in TEK, in communities and

290 have been integrated into the scientific literature (Black et al. 2008; Boulanger-Lapointe et al.

291 2019). Our dataset indicates that, while all of these species have been assessed and ranked in the

292 NWT as secure (S4S5 to S5), none of the rankings have considered for Nunavut. Several

293 publications have also documented traditional uses and knowledge of these species, including

294 TEK in Nunavut, and have documented potential threats to these species due to both climate

295 change and human and animal activity (Team et al. 2016; Boulanger-Lapointe et al. 2019). We

296 have utilized Moerman's Native American Ethnobotany as well as AHPA's HoC list as sources

297 to compile a list of Canadian medicinal plant species, however, we acknowledge that these

298 sources are incomplete and detailed assessments of Canadian territories are warranted. For

299 example, several species documented to be utilized by the Inuit of the Qikiqtaaluk region of

300 Nunavut are not included in this list including Dicranum elongatum Schwaegr., Lycopodium

301 annotinum L., Hockenya peploides (L.) Ehrh., Oxytropis maydelliana (Trautv.), Oxyria digyna 
(L.) Hill., Salix reticulata L., Saxifraga oppositifolia L. and Saxifraga tricuspidata Rothb (Black et al. 2008). This is of particular concern as a direct examination of these species find only one

304 has been assessed in Nunavut, L. annotinum, with an apparently secure Natureserve ranking 305 (S4), while the rest remain unranked (SU). commercial medicinal species (McGuffin et al. 2001). While some of these species have received significant conservation attention due to well-documented problems with unsustainable harvest (McGraw et al. 2010), and considerations such as the impacts of changing climates on

311 wild populations (McGraw et al. 2013), unexpectedly a significant number of these species have 312 not been assessed even at the global level with $46 \%$ of the total list of AHPA HoC $46 \%$ still 313 unranked at the global level and 36\% unranked at the subnational level within Canada.

314 Considering only the 40 botanical commodities which were included in the AHPA Tonnage

315 Report, more than $300 \mathrm{~K} \mathrm{~kg}$ of dried and $19 \mathrm{M} \mathrm{kg}$ fresh material was wild harvested in the United 316 States alone in 2017 (AHPA 2020). Of the species included in the tonnage survey, 22 are species 317 present in Canada, with 18 of those considered native or extirpated species, and it is likely that 318 wild-harvest is also occurring (AHPA 2020). Several of the genera also include species of 319 concern, particularly lady slippers orchid (Cypripedium), including the Ram's-head lady slipper 320 (Cypripedium arietinum $\mathrm{R} . B r$.) which is ranked as critically imperiled (S1, Nova Scotia), 321 imperiled (S2, Manitoba \& Saskatchewan) and vulnerable both subnationally (S3, Ontario, 322 Quebec) and nationally (N3) in Canada. In addition to these species representing a priority for 323 assessment, collection of tonnage data is important in determining the status of Canadian 324 medicinal species. For example, Echinacea is a popular botanical in the US with Echinacea 
325 species together representing a market value of more than $\$ 120 \mathrm{M}$ in the US in 2019 alone.

326 Echinaceae pallida, which was identified as a species of priority for assessment in this study as it

327 is a popular medicinal species, is included in the AHPA Tonnage survey with approx. $18 \mathrm{~kg}$ of

328 root material being wild harvested annually, however it is present in only one province, and has

329 not been assessed (NU; Table 4). Given the limited range of the species in Canada, information

330 on wild harvest and current populations is vital in determining the status of this species (AHPA

3312020 , Smith 2019).

We have examined both overall medicinal species diversity in each subnational region as

334 well as the unique medicinal flora for each region and have identified BC and Ontario as

335 hotspots for medicinal species diversity, with the greatest number of medicinal species and the 336 greatest number of unique species. Species which are unique to a region, in this case a province,

337 are inherently at higher risk than species with broader distributions. This is particularly true 338 given the increased risk, incidence and severity of localized extreme weather events associated

339 with climate change. For these reasons we propose that these species be considered as priority

340 species for assessment. Nationally eight species were identified which are unranked (SU) and

341 which occur in only one subnational region and may represent priorities for assessment.

343 While the above is a good start to understanding the distribution and vulnerability of

344 Canadian medicinal plants and to prioritize specific species/ecosystems for future monitoring, 345 these databases do not fully reflect Canadian-specific biodiversity information. Additionally, the 346 ex situ conservation efforts to date, namely wild Canadian species represented in the Millenium

347 Seedbank at Kew, United Kingdom are still relatively rare and further efforts are needed to 
348 enhance these efforts, which may include establishment of a native Canadian seedbank in

349 Canada. We propose the following three criteria which may assist in prioritizing resources for

350 conservation assessment priority: (a) Current assessment availability or assessment date; (b)

351 Presence in a single province or limited range and (c) Presence of a market for commercial

352 harvest and a or b. Furthermore, while Natureserve, Natureserve Explorer and associated CDCs

353 are a valuable resource, there is no single standard of information available at the subnational or

354 national level. The NWT Infobase and BCCDC are functional examples for frameworks which

355 may be employed to reconcile ethnobotanical, species distribution and plant conservation

356 information for Canadian species within one place, as there is currently no centralized system to

357 monitor the distribution and conservation status of medicinal flora.

359 Competing Interests

360 The authors declare no competing interests

\section{Funding Statement}

363 Funding support from the Natural Sciences and Engineering Research Council of Canada

364 (NSERC) is gratefully acknowledged.

\section{Contributor's Statement}

366 LAEE and CET conducted to data collection, analysis and visualization. All authors contributed

367 to conception and design of the study and participated in writing and editing and approved the 368 final submission.

\section{Data Availability Statement}


371 All data is available in the manuscript or supplementary materials

372

373

374

375

376

377

378

379

380

381

382

383

384

\section{References}

American Herbal Products Association (AHPA). 2018. AHPA launches sustainability subcommittee, formalizing ongoing efforts. American Herbal Products Association. https://www.ahpa.org/News/LatestNews/TabId/96/ArtMID/1179/ArticleID/1034/AHPAlaunches-sustainability-subcommittee-formalizing-ongoing-efforts.aspx Accessed 20 July 2021.

American Herbal Products Association (AHPA). 2020. Tonnage surveys of selected North American wild-harvested plants, 2011-2017. Silver Spring (MD), American Herbal Products Assocation.

Black, P.L., Arnason, J.T., and Cuerrier, A. 2008. Medicinal plants used by the Inuit of Qikiqtaaluk (Baffin Island, Nunavut). Botany 86: 157-163. doi:10.1139/b07-052.

Boulanger-Lapointe, N., Gérin-Lajoie, J., Collier, L.S., Desrosiers, S., Spiech, C., Henry, G.H.R., Hermanutz, L., Lévesque, E., and Cuerrier, A. 2019. Berry plants and Berry Picking in Inuit Nunangat: Traditions in a changing socio-ecological landscape. Polar Res 30:21 doi:10.1007/s10745-018-0044-5.

Boundary Files, 2016 Census. Statistics Canada Catalogue no. 92-160-X.

Boyle, B., Hopkins, N., Lu, Z., Garay, J.A.R., Mozzherin, D., Rees, T., Matasci, N., Narro, M.L., Piel, W.H., Mckay, S.J., Lowry, S., Freeland, C., Peet, R.K., and Enquist, B.J. 2013. The taxonomic name resolution service: an online tool for automated standardization of plant names. BMC Bioinformatics 14: 16. doi:10.1186/1471-2105-14-16. 
394 Brummitt, N.A., Bachman, S.P., Griffiths-Lee, J., Lutz, M., Moat, J.F., Farjon, A., Donaldson, 395 J.S., Hilton-Taylor, C., Meagher, T.R., Albuquerque, S., Aletrari, E., Andrews, A.K., 396 Atchison, G., Baloch, E., Barlozzini, B., Brunazzi, A., Carretero, J., Celesti, M., Chadburn, 397 H., Cianfoni, E., Cockel, C., Coldwell, V., Concetti, B., Contu, S., Crook, V., Dyson, P., 398 Gardiner, L., Ghanim, N., Greene, H., Groom, A., Harker, R., Hopkins, D., Khela, S., 399 Lakeman-Fraser, P., Lindon, H., Lockwood, H., Loftus, C., Lombrici, D., Lopez-Poveda, L., 400 Lyon, J., Malcolm-Tompkins, P., McGregor, K., Moreno, L., Murray, L., Nazar, K., Power, 401 E., Tuijtelaars, M.Q., Salter, R., Segrott, R., Thacker, H., Thomas, L.J., Tingvoll, S., 402 Watkinson, G., Wojtaszekova, K., and Lughadha, E.M.N. 2015. Green Plants in the Red: A 403 Baseline global assessment for the IUCN sampled red list index for plants. PLoS ONE 10: $404 \quad$ e0135152. doi:10.1371/journal.pone.0135152.

405 Government of Canada. 2019. Canada’s Changing Climate Report. 1-444.

406 Committee on the Status of Endangered Wildlife in Canada (COSEWIC). 2021. COSEWIC 407 Status Reports. [Online] Available: https://www.canada.ca/en/services/environment/wildlife$408 \quad$ plants-species/species-risk.html.

409 Canadian Endangered Species Conservation Council. 2016. Wild Species 2015: The General 410 Status of Species in Canada. National General Status Working Group.

411 McGraw, J.B., Lubbers, A.E., Voort, M.V. der, Mooney, E.H., Furedi, M.A., Souther, S., Turner, 412 J.B., and Chandler, J. 2013. Ecology and conservation of ginseng (Panax quinquefolius) in a 413 changing world. Ann Ny Acad Sci 1286: 62-91. doi:10.1111/nyas.12032. 
414 McGraw, J.B., Souther, S., and Lubbers, A.E. 2010. Rates of harvest and compliance with

415 regulations in natural populations of American ginseng (Panax quinquefolius L.). Nat Area J

416 30: 202-210. doi:10.3375/043.030.0207.

417 McGuffin, M., Kartesz, J.T., Leung, A.Y., and Tucker, A.O. 2001. Herbs of Commerce.

418 American Herbal Products Association (AHPA). Silver Spring (MD).

419 Moerman, D.E. 2009. Native American Ethnobotany. TimberPress Inc, Portland, Oregan.

420 Oliver LE, Leaman DJ. 2018. Protecting Goldenseal: how status assessments inform

421 conservation. HerbalGram 119:40-55

422 Species at Risk Act (SARA), Last amended April 23, 2021. Minister of Justice, Government of 423 Canada. Accessed 20 July, 2021. https:/laws.justice.gc.ca/eng/acts/S-15.3/

424 Smith, T., May, G., Eckl, V., and Reynolds, C.M. 2020. US Sales of Herbal Supplements 425 Increase by $8.6 \%$ in 2019 . HerbalGram: $54-69$.

426 Team, I.R., Bunce, A., Ford, J., Harper, S., and Edge, V. 2016. Vulnerability and adaptive 427 capacity of Inuit women to climate change: a case study from Iqaluit, Nunavut. Nat Hazards 428 83: 1419-1441. doi:10.1007/s11069-016-2398-6.

429 United Plant Savers (UPS). 2021. Species at Risk. [Online] Available:

430 https://www.unitedplantsavers.org/species-at-risk. 


\section{Tables}

433

434

435

Table 1. Residual analysis of native Canadian medicinal species by Natureserve Ranking.

\begin{tabular}{|c|c|c|c|c|c|c|}
\hline & \multicolumn{2}{|c|}{ Observed } & \multicolumn{2}{|c|}{$\begin{array}{l}\text { Expected Best Fit }\left(\mathrm{R}^{2}=0.959\right) \\
\text { \# Expected }\end{array}$} & \multicolumn{2}{|c|}{$\begin{array}{l}\text { Expected Forcing }(0,0) \\
\text { \# Expected Medicinal }\end{array}$} \\
\hline N1 & 54 & 232 & 50.56 & 3.44 & 89.27 & -35.27 \\
\hline $\mathrm{N} 2$ & 51 & 246 & 56.58 & -5.58 & 94.66 & -43.66 \\
\hline N3 & 72 & 366 & 108.16 & -36.16 & 140.84 & -68.84 \\
\hline N4 & 184 & 771 & 282.23 & -98.23 & 296.68 & -112.68 \\
\hline N5 & 779 & 1800 & 724.49 & 54.51 & 692.64 & 86.36 \\
\hline $\mathrm{NH}$ & 3 & 27 & -37.54 & 40.54 & 10.39 & -7.39 \\
\hline NNR & 58 & 334 & 94.40 & -36.40 & 128.52 & -70.52 \\
\hline $\mathrm{NNU}$ & 4 & 52 & -26.80 & 30.80 & 20.01 & -16.01 \\
\hline $\mathrm{NX}$ & 8 & 23 & -39.26 & 47.26 & 8.85 & -0.85 \\
\hline
\end{tabular}

436

437 
438 Table 2. Residual analysis of native Canadian medicinal taxa listed in the Species at Risk Act 439 (SARA) by family. Note only the top 11 families are included.

440

\begin{tabular}{c|cc|cc}
\hline & & & & \\
& Medicinal & All & $\begin{array}{c}\text { Expected Medicinal } \\
\text { Species }\end{array}$ & Residuals \\
\hline Fabaceae & 6 & 11 & 2.46 & 3.54 \\
Orobanchaceae & 0 & 10 & 2.24 & -2.24 \\
Cyperaceae & 0 & 9 & 2.02 & -2.02 \\
Gentianaceae & 3 & 5 & 1.16 & 1.84 \\
Orchidaceae & 0 & 8 & 1.81 & -1.81 \\
Araliaceae & 2 & 2 & 0.50 & 1.50 \\
Asparagaceae & 2 & 2 & 0.50 & 1.50 \\
Brassicaceae & 0 & 4 & 0.94 & -0.94 \\
Salicaceae & 0 & 4 & 0.94 & -0.94 \\
Boraginaceae & 0 & 3 & 0.72 & -0.72 \\
Onagraceae & 0 & 3 & 0.72 & -0.72 \\
\hline
\end{tabular}


443 Table 3. Medicinal species which are unique to one Canadian province or territory with an S1 444 (critically imperiled) ranking

\begin{tabular}{|c|c|c|c|c|c|c|}
\hline Scientific Name & $\begin{array}{c}\text { Rounded } \\
\text { Global } \\
\text { Rank }^{\mathbf{a}} \\
\end{array}$ & $\begin{array}{c}\text { COSEWIC }^{1} / \mathrm{SARA}^{2} \\
\text { Status } \\
\end{array}$ & $\begin{array}{c}\text { National } \\
\text { Rank }^{\mathbf{a}}\end{array}$ & $\begin{array}{c}\text { Subnational } \\
\text { Rank }^{\mathbf{a}}\end{array}$ & $\begin{array}{c}\text { US } \\
\text { Rank }^{\mathbf{a}}\end{array}$ & $\begin{array}{c}\text { Province or } \\
\text { Territory }\end{array}$ \\
\hline $\begin{array}{c}\text { Machaeranthera tanacetifolia } \\
\text { (Kunth) Nees }\end{array}$ & G5 & & N1 & S1 & N3N5 & $\mathrm{AB}$ \\
\hline Oxytropis lagopus Nutt. & G4 & Threatened & N1 & S1 & NNR & $\mathrm{AB}$ \\
\hline Lupinus wyethii S. Watson & G5 & & N1 & S1 & NNR & $\mathrm{AB}$ \\
\hline Fraxinus latifolia Benth. & G5 & & N1N2 & S1S2 & N4 & $\mathrm{BC}$ \\
\hline Adiantum capillus-veneris L. & G5 & Endangered & N1 & S1 & N5 & $\mathrm{BC}$ \\
\hline $\begin{array}{l}\text { Centaurium muehlenbergii } \\
\text { (Griseb.) W. Wight ex Piper } \\
\text { Lupinus rivularis Douglas ex }\end{array}$ & G5 & Endangered & N1 & S1 & N5? & $\mathrm{BC}$ \\
\hline $\begin{array}{l}\text { Lindl. } \\
\text { Marah oreganus (Torr. ex S. }\end{array}$ & G3 & Endangered & N1 & S1 & NNR & $\mathrm{BC}$ \\
\hline Watson) Howell & G5 & Endangered & N1 & S1 & NNR & $\mathrm{BC}$ \\
\hline $\begin{array}{c}\text { Centaurium exaltatum (Griseb.) W. } \\
\text { Wight ex Piper }\end{array}$ & G5 & & N1N2 & S1S2 & NNR & $\mathrm{BC}$ \\
\hline Delphinium carolinianum Walter & G5 & & N1 & S1 & NNR & MB \\
\hline $\begin{array}{l}\text { Hydrocotyle umbellata L. } \\
\text { Castanea dentata (Marshall) }\end{array}$ & G5 & Special Concern & N1 & S1 & N5 & NS \\
\hline Borkh. & G3 & Endangered & N1N2 & S1S2 & N3 & $\mathrm{ON}$ \\
\hline Plantago cordata Lam. & G4 & Endangered & N1 & S1 & N4 & $\mathrm{ON}$ \\
\hline Baptisia tinctoria (L.) R. Br. & G5 & & $\mathrm{N} 1 \mathrm{~N} 2$ & S1S2 & N4N5 & ON \\
\hline Aureolaria virginica (L.) Pennell & G5 & Endangered & N1 & S1 & N5 & $\mathrm{ON}$ \\
\hline Betula lenta L. & G5 & Endangered & N1 & S1 & N5 & ON \\
\hline Ipomoea pandurata (L.) G. Mey. & G5 & & N1 & S1 & N5 & ON \\
\hline Phacelia purshii Buckley & G5 & & N1 & S1 & N5 & ON \\
\hline Quercus ilicifolia Wangenh. & G5 & & N1 & S1 & N5 & ON \\
\hline Tephrosia virginiana (L.) Pers. & G5 & Endangered & N1 & S1 & N5 & ON \\
\hline Vitis vulpina L. & G5 & & N1 & S1 & N5 & ON \\
\hline Heuchera americana $\mathrm{L}$. & G5 & & N1 & S1 & N5 & $\mathrm{ON}$ \\
\hline Hieracium venosum $\mathrm{L}$. & G5 & & $\mathrm{N} 1 \mathrm{~N} 2$ & S1? & N5 & ON \\
\hline Uvularia perfoliata $\mathrm{L}$. & G5 & & N1N2 & S1S2 & N5 & $\mathrm{ON}$ \\
\hline Chaerophyllum procumbens (L.) & & & & & & \\
\hline Crantz & G5 & & $\mathrm{N} 1 \mathrm{~N} 2$ & S1S2 & N5 & $\mathrm{ON}$ \\
\hline Aesculus glabra Willd. & G5 & & N1 & S1 & N5? & ON \\
\hline $\begin{array}{l}\text { Galium concinnum Torr. \& A. } \\
\text { Gray }\end{array}$ & G5 & & N1 & S1 & N5? & $\mathrm{ON}$ \\
\hline Sisyrinchium albidum Raf. & G5 & & N1 & S1 & N5? & ON \\
\hline Triosteum perfoliatum L. & G5 & & N1N2 & S1 & N5? & $\mathrm{ON}$ \\
\hline
\end{tabular}




\begin{tabular}{|c|c|c|c|c|c|c|}
\hline Scientific Name & $\begin{array}{c}\text { Rounded } \\
\text { Global } \\
\text { Rank }^{\mathbf{a}}\end{array}$ & $\begin{array}{c}\text { COSEWIC }^{1} / \mathrm{SARA}^{2} \\
\text { Status }\end{array}$ & $\begin{array}{c}\text { National } \\
\text { Rank }^{\mathbf{a}}\end{array}$ & $\begin{array}{c}\text { Subnational } \\
\text { Rank }^{\mathbf{a}}\end{array}$ & $\begin{array}{l}\text { US } \\
\text { Rank }^{\mathbf{a}}\end{array}$ & $\begin{array}{l}\text { Province or } \\
\text { Territory }\end{array}$ \\
\hline $\begin{array}{c}\text { Agastache scrophulariifolia } \\
\text { (Willd.) Kuntze }\end{array}$ & G4 & & $\mathrm{N} 1$ & S1 & NNR & $\mathrm{ON}$ \\
\hline Asclepias quadrifolia Jacq. & G5 & Endangered & $\mathrm{N} 1$ & S1 & NNR & $\mathrm{ON}$ \\
\hline Blephilia ciliata (L.) Benth. & G5 & & N1 & $\mathrm{S} 1$ & NNR & ON \\
\hline $\begin{array}{l}\text { Gentiana alba Muhl. ex Nutt. } \\
\text { Pycnanthemum incanum (L.) }\end{array}$ & G4 & Endangered & N1 & S1 & NNR & $\mathrm{ON}$ \\
\hline $\begin{array}{l}\text { Michx. } \\
\text { Senna hebecarpa (Fernald) Irwin }\end{array}$ & G5 & Endangered & N1 & $\mathrm{S} 1$ & NNR & ON \\
\hline \& Barneby & G5 & & N1 & S1 & NNR & $\mathrm{ON}$ \\
\hline Silphium laciniatum L. & G5 & & $\mathrm{N} 1$ & S1 & NNR & $\mathrm{ON}$ \\
\hline Solidago ulmifolia Muhl. ex Willd. & G5 & & N1 & S1 & NNR & $\mathrm{ON}$ \\
\hline Viola pedata $\mathrm{L}$. & G5 & Endangered & N1 & S1 & NNR & $\mathrm{ON}$ \\
\hline Camassia scilloides (Raf.) Cory & G4 & Threatened & N1 & S1 & NNR & $\mathrm{ON}$ \\
\hline
\end{tabular}

$446{ }^{1}$ Committee for the Status of Endangered Wildlife in Canada

$447 \quad{ }^{2}$ Species at Risk Act

448 â G,Global Rank; N, National; S, Subnational Rank; NR, unranked; NA, not applicable; U,

449 Unrankable; H, possibly extirpated; X, presumed extirpated; 1, Critically Imperiled; 2,

450 Imperiled; 3, Vulnerable; 4, Apparently Secure; 5, Secure; ? indicates an inexact numeric rank 


\begin{tabular}{|c|c|c|c|c|c|c|c|c|c|}
\hline Scientific Name & Common Name & $\begin{array}{c}\text { Rounded } \\
\text { Global } \\
\text { Rank }^{\mathbf{a}} \\
\end{array}$ & $\begin{array}{c}\text { COSEWIC }^{1 /} \\
\text { SARA }^{2} \text { Status } \\
\end{array}$ & $\begin{array}{c}\text { Canada } \\
\text { Rank }^{\mathbf{a}} \\
\end{array}$ & $\begin{array}{c}\text { Subnational } \\
\text { Rank }^{\mathbf{a}}\end{array}$ & $\begin{array}{l}\text { I BCCDC } \\
\text { Rank }^{\mathbf{a}} \\
\end{array}$ & $\begin{array}{c}\text { US } \\
\text { Rank }^{\mathbf{a}}\end{array}$ & Province & $\begin{array}{c}\text { Provincial } \\
\text { Assessment }^{4} \\
\end{array}$ \\
\hline $\begin{array}{l}\text { Arceuthobium } \\
\text { campylopodum } \\
\text { Engelm. }\end{array}$ & $\begin{array}{l}\text { Western Dwarf- } \\
\text { mistletoe }\end{array}$ & G5 & & $\mathrm{N} 4 ?$ & SNR & & NNR & $\mathrm{BC}$ & Yellow \\
\hline $\begin{array}{l}\text { Malus coronaria }(\mathrm{L} .) \\
\text { Mill. }\end{array}$ & Sweet Crabapple & G5 & & NNR & SNR & & N5 & $\mathrm{ON}$ & \\
\hline $\begin{array}{c}\text { Rubus leucodermis } \\
\text { Douglas ex Torr. \& } \\
\text { A. Gray }\end{array}$ & $\begin{array}{l}\text { White-stem } \\
\text { Raspberry }\end{array}$ & G5 & & N5 & SNR & & NNR & $\mathrm{BC}$ & \\
\hline $\begin{array}{l}\text { Thaspium barbinode } \\
\text { (Michx.) Nutt. }\end{array}$ & $\begin{array}{c}\text { Hairy-joint } \\
\text { Meadow-parsnip }\end{array}$ & G5 & & NNR & SNR & & N5 & ON & \\
\hline $\begin{array}{l}\text { Echinacea pallida } \\
\text { (Nutt.) Nutt. }\end{array}$ & $\begin{array}{l}\text { Pale Purple } \\
\text { Coneflower }\end{array}$ & G4 & & NU & SNR & & N4 & ON & \\
\hline $\begin{array}{l}\text { Solidago speciosa } \\
\text { Nutt. }\end{array}$ & Showy Goldenrod & G5 & Endar & NNR & SNR & & N5 & $\mathrm{ON}$ & \\
\hline $\begin{array}{l}\text { Asarum caudatum } \\
\text { Lindl. }\end{array}$ & $\begin{array}{l}\text { Longtail Wild } \\
\text { Ginger, BC } \\
\text { wildginger }\end{array}$ & G5 & & NNR & SNR & S5 (2019) & NNR & $\mathrm{BC}$ & Yellow \\
\hline $\begin{array}{l}\text { Rubus frondosus } \\
\text { Bigelow }\end{array}$ & Yankee Blackberry & G5 & & NNR & SU & & NNR & $\mathrm{ON}$ & \\
\hline $\begin{array}{l}\text { Nicotiana attenuata } \\
\text { Torr. ex S. Watson }\end{array}$ & Coyote Tobacco & G4 & & NU & SU & & NNR & $\mathrm{BC}$ & Unknown \\
\hline $\begin{array}{ll}454 & { }^{1} \text { Commi } \\
455 & { }^{2} \text { Species } \\
456 & { }^{3} \text { British } \\
457 & { }^{4} \text { Provin } \\
458 & { }^{\mathrm{a}} \text { G,Glob } \\
459 & \text { Unranka } \\
460 & \text { Imperile } \\
461 & \end{array}$ & $\begin{array}{l}\text { ttee for the Status } \\
\text { at Risk Act } \\
\text { Columbia Conser } \\
\text { cial listing by Spe } \\
\text { al Rank; N, Natior } \\
\text { ble; H, possibly e } \\
\text { d; 3, Vulnerable; }\end{array}$ & $\begin{array}{l}\text { f Endang } \\
\text { ition Data } \\
\text { es at Risk } \\
\text { l; S, Subr } \\
\text { irpated; } Y \\
\text { Apparen }\end{array}$ & $\begin{array}{l}\text { ed Wildlife it } \\
\text { Center, brack } \\
\text { Ontario (SAR } \\
\text { ational Rank; } \\
\text { presumed ex } \\
\text { y Secure; 5, S }\end{array}$ & $\begin{array}{l}\text { n Canad } \\
\text { ets indic } \\
\text { O) or B } \\
\text { NR, un } \\
\text { tirpated } \\
\text { Secure; }\end{array}$ & $\begin{array}{l}\text { ate year la } \\
\text { CCDC, inc } \\
\text { anked; NA } \\
\text { 1, Critica } \\
\text { indicates }\end{array}$ & $\begin{array}{l}\text { st assesse } \\
\text { cluded wl } \\
\text { d, not app } \\
\text { lly Imper } \\
\text { an inexac }\end{array}$ & $\begin{array}{l}\text { d } \\
\text { here in } \\
\text { licable } \\
\text { iled; } 2 \\
\text { t nume }\end{array}$ & $\begin{array}{l}\text { dicated } \\
; \mathrm{U}, \\
\text { eric rank }\end{array}$ & \\
\hline
\end{tabular}


463 Table 5. American Herbal Products Association (AHPA) Herbs of Commerce species unique to a 464 single province/territory.

\begin{tabular}{|c|c|c|c|c|c|c|}
\hline Scientific Name & $\begin{array}{c}\text { Rounded } \\
\text { Global } \\
\text { Rank } \\
\end{array}$ & $\begin{array}{l}\text { COSEWIC } 1 / \\
\text { SARA }^{2} \text { Status } \\
\end{array}$ & $\begin{array}{c}\text { National } \\
\text { Rank }^{\mathbf{a}}\end{array}$ & $\begin{array}{c}\text { Subnational } \\
\text { Rank }^{\mathbf{a}}\end{array}$ & $\begin{array}{c}\text { US } \\
\text { Rank }^{\mathbf{a}} \\
\end{array}$ & Province \\
\hline Aletris farinosa $\mathrm{L}$. & G5 & Endangered & $\mathrm{N} 2$ & S2 & N5 & $\mathrm{ON}$ \\
\hline Apium graveolens $\mathrm{L}$. & GNR & & NNA & SNA & NNA & NS \\
\hline Baptisia tinctoria (L.) R. Br. & G5 & & N1N2 & S1S2 & N4N5 & ON \\
\hline Betula lenta $\mathrm{L}$. & G5 & Endangered & N1N2 & S1 & N5 & $\mathrm{ON}$ \\
\hline Castanea dentata (Marshall) Borkh. & G3 & Endangered & N1N2 & S1S2 & N3 & $\mathrm{ON}$ \\
\hline Collinsonia canadensis $\mathrm{L}$. & G5 & & N4 & S4 & N5 & ON \\
\hline Dioscorea villosa $\mathrm{L}$. & G4 & & N4 & S4 & N4N5 & $\mathrm{ON}$ \\
\hline Echinacea pallida (Nutt.) Nutt. & G4 & & NU & SNR & N4 & $\mathrm{ON}$ \\
\hline Equisetum telmateia Ehrh. & G5 & & N5 & S5 & NNR & $\mathrm{BC}$ \\
\hline Euonymus atropurpureus Jacq. & G5 & & N3 & $\mathrm{S} 3$ & N4N5 & $\mathrm{ON}$ \\
\hline Frangula purshiana (DC.) A. Gray & G5 & & N5 & S5 & N4 & $\mathrm{BC}$ \\
\hline Heuchera micrantha Douglas ex Lindl. & G5 & & N5 & S5 & N5 & $\mathrm{BC}$ \\
\hline Hydrastis canadensis $\mathrm{L}$. & G3 & $\begin{array}{c}\text { Special } \\
\text { Concern/Threatened }\end{array}$ & $\mathrm{N} 2$ & S2 & N3N4 & ON \\
\hline Mahonia nervosa (Pursh) Nutt. & G5 & & N5 & S5 & NNR & $\mathrm{BC}$ \\
\hline Sassafras albidum (Nutt.) Nees & G5 & & N4 & S4 & N5 & $\mathrm{ON}$ \\
\hline Artemisia douglasiana Besser & G5 & & $\mathrm{N} 1 \mathrm{~N} 2$ & S1S2 & NNR & $\mathrm{BC}$ \\
\hline Ballota nigra $\mathrm{L}$. & GNR & & NNA & SNA & NNA & $\mathrm{ON}$ \\
\hline Chamaelirium luteum (L.) A. Gray & G5 & & NX & SX & N5 & $\mathrm{ON}$ \\
\hline Eclipta prostrata (L.) L. & G5 & & N1? & S1? & N5 & $\mathrm{ON}$ \\
\hline Forsythia suspensa (Thunb.) Vahl & GNR & & NNA & SNA & NNA & $\mathrm{ON}$ \\
\hline Glehnia littoralis F. Schmidt ex Miq. & G5 & & N3 & S3 & NNR & $\mathrm{BC}$ \\
\hline Lonicera japonica Thunb. & GNR & & NNA & SNA & NNA & $\mathrm{ON}$ \\
\hline Mentha pulegium $\mathrm{L}$. & GNR & & NNA & SNA & NNA & $\mathrm{BC}$ \\
\hline Paeonia lactiflora Pall. & GNR & & NNA & SNA & NNA & $\mathrm{ON}$ \\
\hline Paeonia officinalis L. & GNR & & NNA & SNA & NNA & $\mathrm{ON}$ \\
\hline Salvia sclarea $\mathrm{L}$. & GNR & & NNA & SNA & NNA & $\mathrm{ON}$ \\
\hline Stachys officinalis (L.) Trevis. & GNR & & NNA & SNA & NNA & PE \\
\hline Teucrium scorodonia L. & GNR & & NNA & SNA & NNA & QC \\
\hline Vaccinium pallidum Aiton & G5 & & N4 & S4 & N5 & $\mathrm{ON}$ \\
\hline
\end{tabular}

$466{ }^{1}$ Committee for the Status of Endangered Wildlife in Canada

$467 \quad{ }^{2}$ Species at Risk Act

468 a'G,Global Rank; N, National; S, Subnational Rank; NR, unranked; NA, not applicable; U, 469 Unrankable; H, possibly extirpated; X, presumed extirpated; 1, Critically Imperiled; 2,

470 Imperiled; 3, Vulnerable; 4, Apparently Secure; 5, Secure; ? indicates an inexact numeric rank 
472 Table 6. American Herbal Products Association (AHPA) Herbs of Commerce species listed 473 under the Species at Risk Act (SARA).

\begin{tabular}{|c|c|c|c|c|}
\hline Family & Scientific Name & $\begin{array}{c}\text { NatureServe } \\
\text { Rounded } \\
\text { Global } \\
\text { Rank } \\
\end{array}$ & SARA Status & Distribution \\
\hline Liliaceae & Aletris farinosa $\mathrm{L}$. & G5 & Endangered & $\mathrm{ON}$ \\
\hline Betulaceae & $\begin{array}{l}\text { Betula lenta } \mathrm{L} . \\
\text { Castanea dentata (Marshall) }\end{array}$ & G5 & Endangered & $\mathrm{ON}$ \\
\hline Fagaceae & Borkh. & G3 & Endangered & $\mathrm{ON}$ \\
\hline Araliaceae & Panax quinquefolius $\mathrm{L}$. & G3 & Endangered & $\mathrm{ON}, \mathrm{QC}$ \\
\hline Juglandaceae & Juglans cinerea $\mathrm{L}$. & G3 & Endangered & $\mathrm{MB}, \mathrm{NB}, \mathrm{NS}, \mathrm{ON}, \mathrm{PE}, \mathrm{QC}$ \\
\hline Ranunculaceae & Hydrastis canadensis L. & G3 & Threatened & ON \\
\hline Agavaceae & Yucca glauca Nutt. & G5 & Threatened & $\mathrm{AB}, \mathrm{SK}$ \\
\hline
\end{tabular}




\section{Figure Captions}

Figure 1. (a) All medicinal plant species present in Canada by province or territory, (b) Native medicinal plant species assessed present by province or territory, where native is defined by the USDA PLANTS floristic database; (c) distribution of Natureserve conservation rankings (Percent) for all medicinal species in Canada; and (d) distribution of Natureserve conservation rankings for all Canadian species, where NNA (Not Applicable), NNR (Unranked), NH (Possibly Extirpated), NX (Presumed Extirpated), N1 (Critically Imperiled), N2 (Imperiled), N3 (Vulnerable), N4 (Apparently Secure), N5 (Secure). Shape files from Cartographic Boundary Files portrayed in Lambert conformal conic projection based on the North American Datum of 1983 (NAD83), 2016 Census, Statistics Canada.

Figure 2. Distribution of native Canadian medicinal species unique to a single province or territory. Inset, Natureserve subnational ranking of native Canadian species unique to a single province or territory where SNA (Not Applicable), SNR (Unranked), SH (Possibly Extirpated), SX (Presumed Extirpated), S1 (Critically Imperiled), S2 (Imperiled), S3 (Vulnerable), S4 (Apparently Secure), S5 (Secure). Shape files from Cartographic Boundary Files portrayed in Lambert conformal conic projection based on the North American Datum of 1983 (NAD83), 2016 Census, Statistics Canada.

Figure 3. (a) Year medicinal species possessing Natureserve national rankings were last updated and (b) proportional of species assessed by province/territory.

Figure 4. Distribution of species by family ranked as (a) N1 or (b) N2 by family where size of the bubble indicates total number of native Canadian species in a particular family and the line of best fit is the linear regression line of all species with the ranking vs all medicinal species with the designated ranking. Families above the line are families where medicinal species are overrepresented in the family for the rank level, while those below the line are underrepresented by the rank level.

Figure 5. Regression analysis of number of SARA-listed native Canadian medicinal species by family vs total SARA-listed native Canadian species where families above the line of best fit are over-represented and those under the line are under-represented. Size of bubbles indicates total number of native species present in the family in Canada and the lighter the colour the greater the number of native Canadian medicinal species in the family.

Figure 6. Percent of species by Natureserve subnational ranking in each province/territory. Darker indicates a higher proportion, for combined categories e.g. S3S5 the species is included in both S3 and S5. SNA (Not Applicable), SNR (Unranked), SH (Possibly Extirpated), SX (Presumed Extirpated), S1 (Critically Imperiled), S2 (Imperiled), S3 (Vulnerable), S4 (Apparently Secure), S5 (Secure). Shape files from Cartographic Boundary Files portrayed in Lambert conformal conic projection based on the North American Datum of 1983 (NAD83), 2016 Census, Statistics Canada.

Figure 7. Natureserve subnational rankings of native Canadian species reported to occur in the Northwest Territories (NWT; top), British Columbia (BC, middle) and Nunavut (NU, bottom), 
522 where SNA (Not Applicable), SNR (Unranked), SH (Possibly Extirpated), SX (Presumed 523 Extirpated), S1 (Critically Imperiled), S2 (Imperiled), S3 (Vulnerable), S4 (Apparently Secure), 524 S5 (Secure).

Figure 8. American herbal products association (AHPA) herbs of commerce (HoC) (a) Global 528 rank of all HoC species reported to occur in Canada (b) Subnational ranking (c) Provincial distribution of $\mathrm{HoC}$ unique to a single province or territory and (d) Distribution of unique HoC 5314 (Apparently Secure), 5 (Secure), NR (Not Ranked), NA (Not Applicable), U (Unrankable), X 532 (Presumed Extirpated), H (Possibly Extirpated). 


\section{Supplementary Materials}

535

536

537

538

539

540

541

542

543

544

545

546
Supplementary Table 1. Comprehensive list of medicinal species included in the study acquired from the Native American Ethnobotany Database

Supplementary Table 2. List of species included in the study which are included in the American Herbal Products Association (AHPA) Herbs of Commerce.

Supplementary Table 3. Species queried for subnational ranking and conservation status in British Columbia through the BC Conservation Data Centre.

Supplementary Table 4. Species queried for subnational ranking and conservation status in Nunavut through Natureserve Explorer.

Supplementary Table 5. Species queried for subnational ranking and conservation status in the Northwest Territories through NWT Species Infobase. 


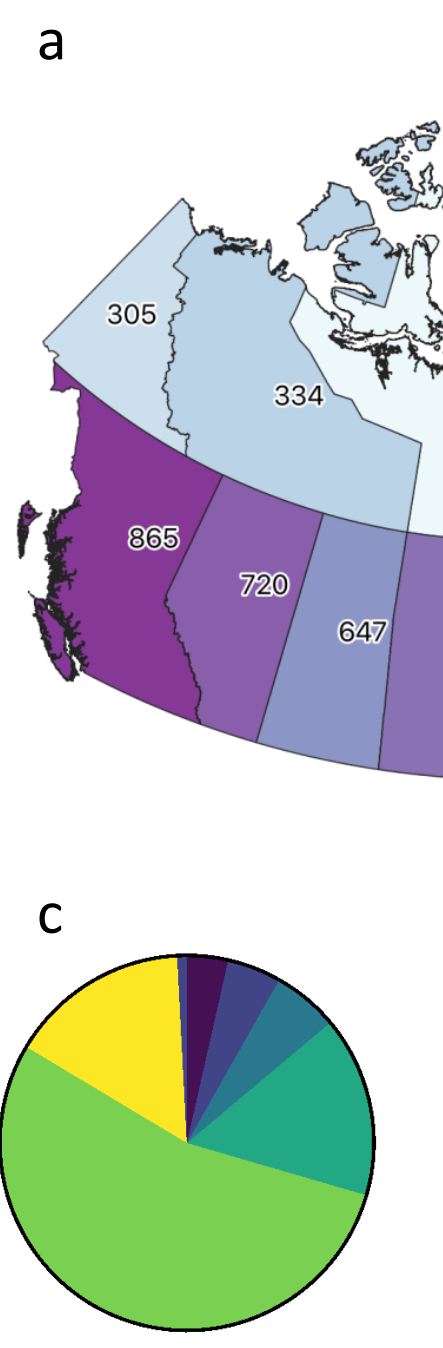

b

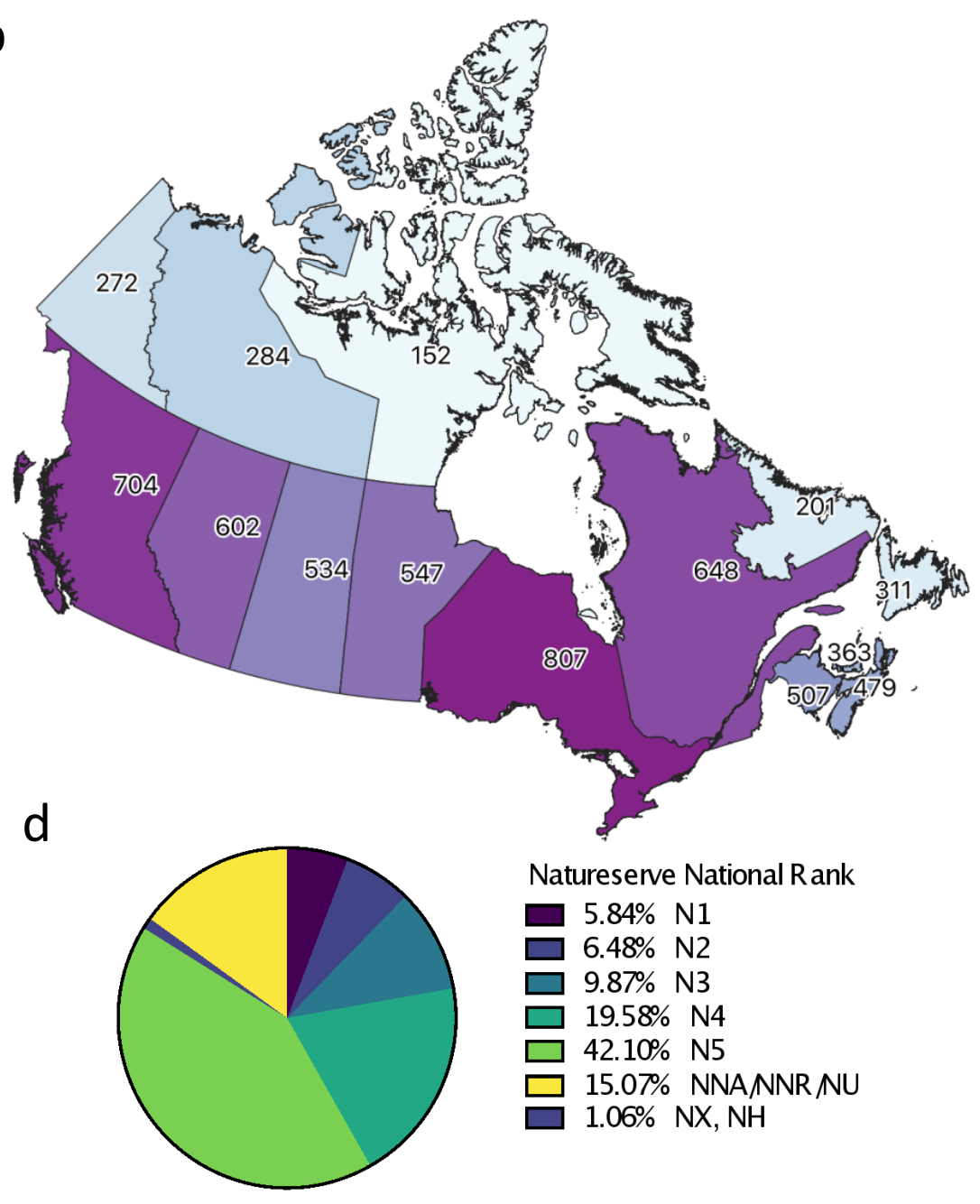

Natureserve National Rank

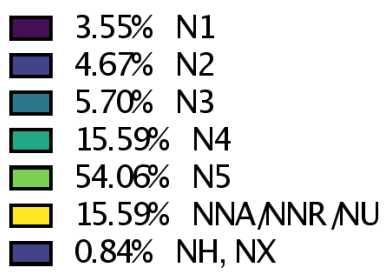

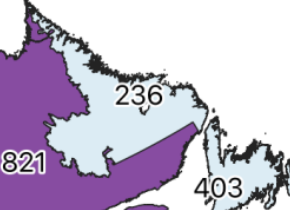

Pि4 40 in 56516641

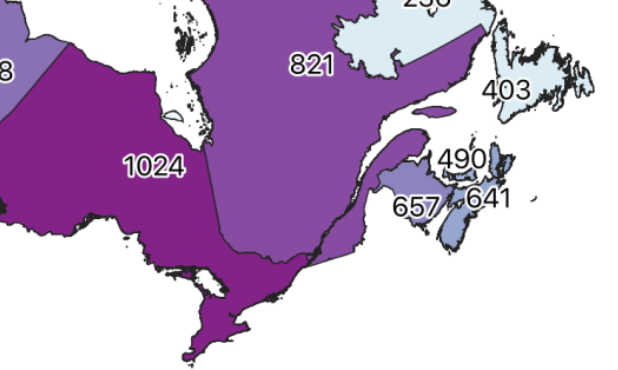

हैy

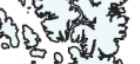

(3)

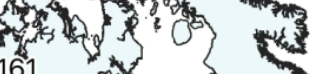

急

of
Natureserve National Rank

$5.84 \% \mathrm{~N} 1$

$6.48 \% \mathrm{~N} 2$

$1.06 \% \mathrm{NX}, \mathrm{NH}$ 


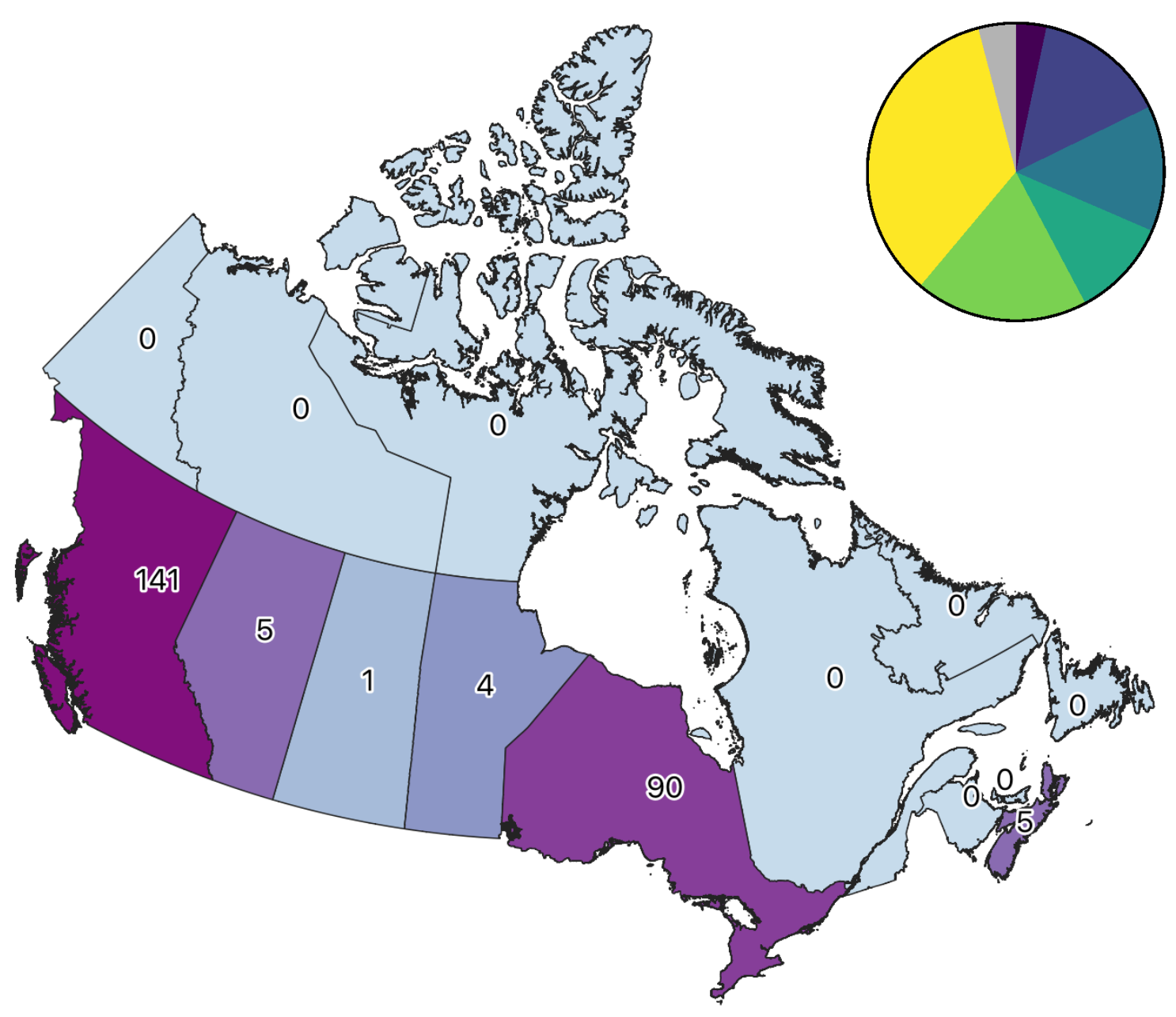

Natureserve Subnational Rank

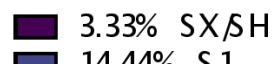

$\square 14.44 \%$ S 1

$\square 13.70 \%$ S2

$\square 10.74 \%$ S 3

$\square 18.89 \%$ S 4

$\square 34.81 \%$ S 5

$\square$ 4.07\% SNRSNASU 
a

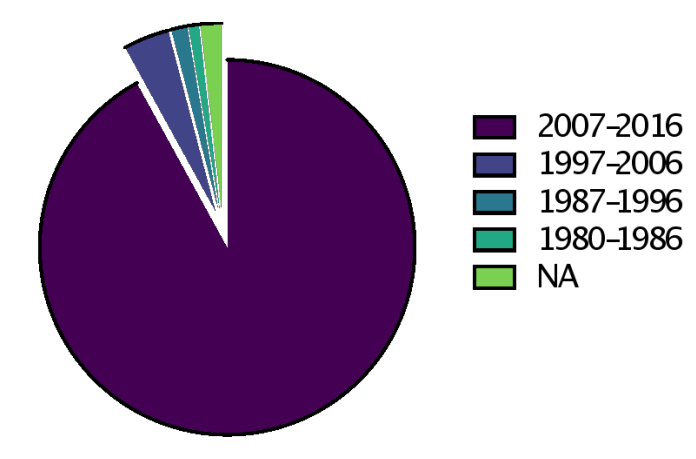

b

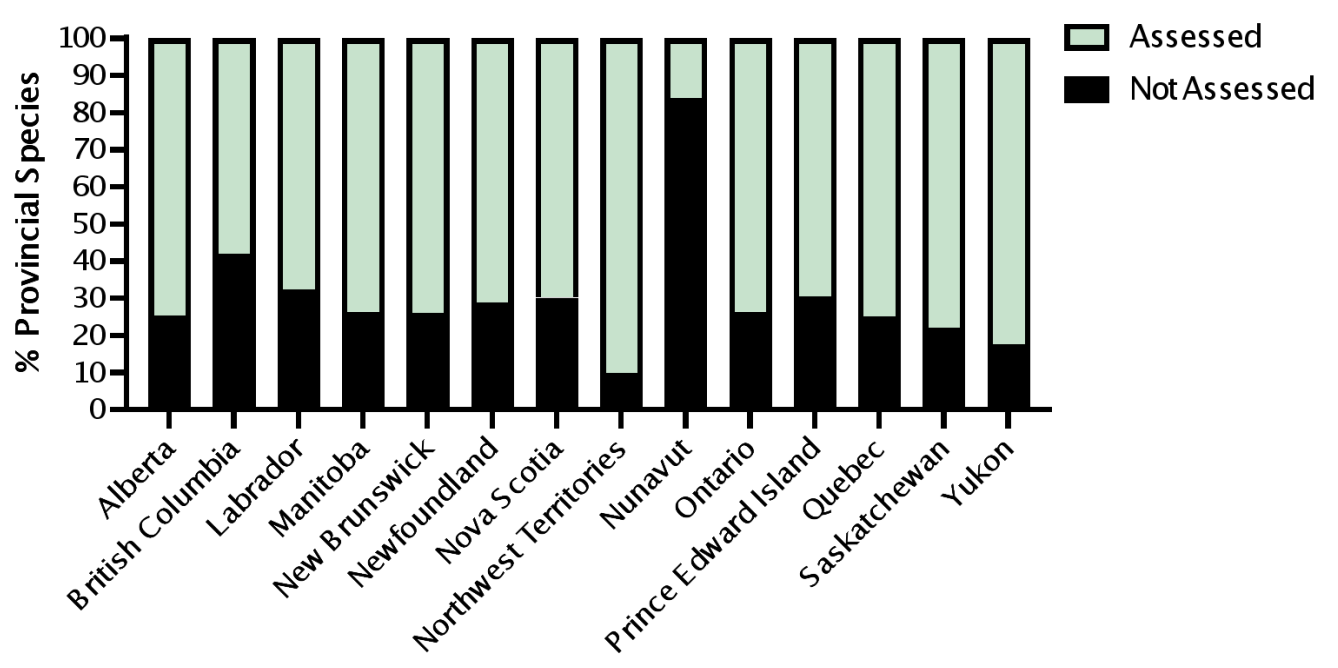




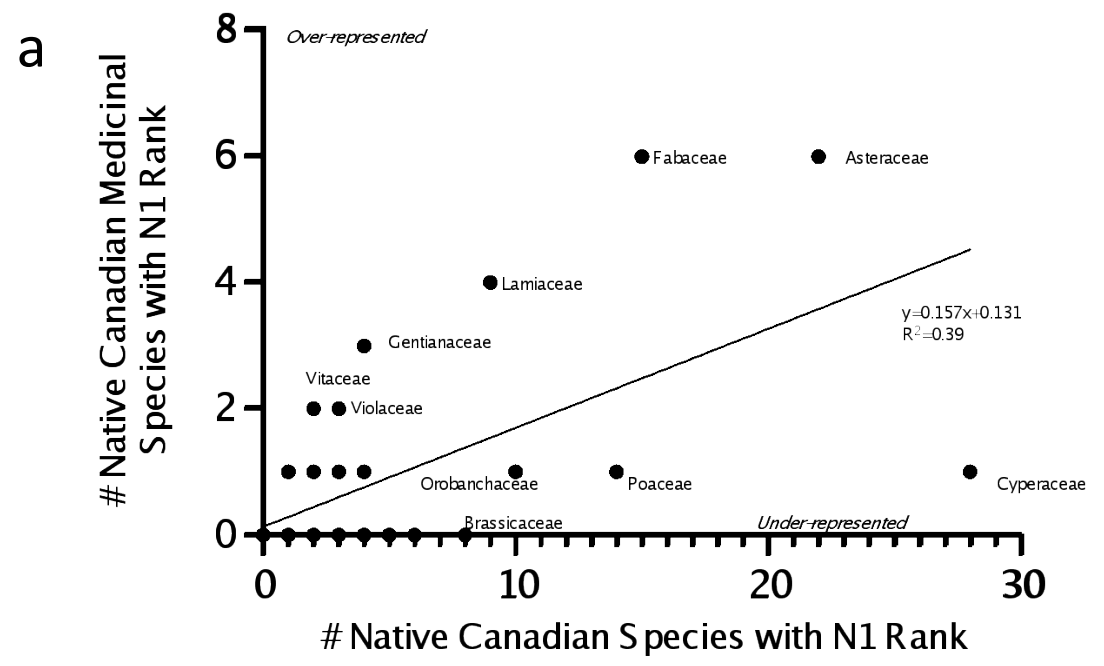

b

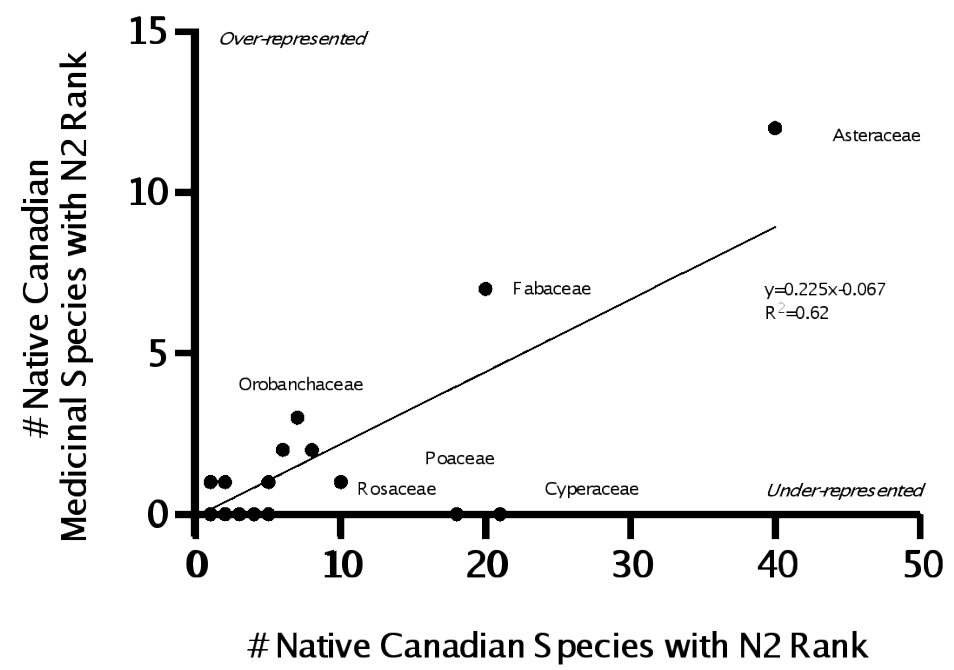




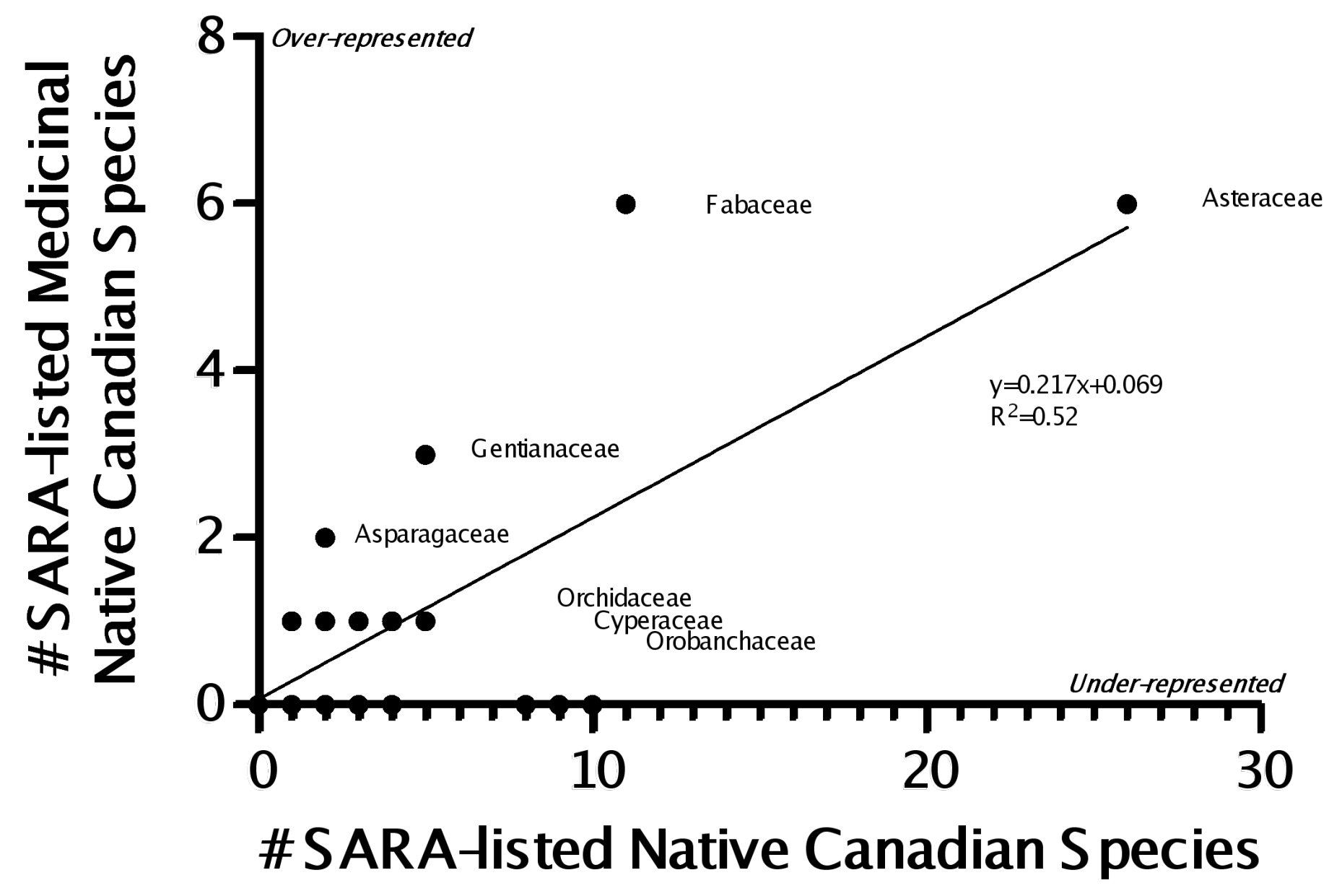


S1

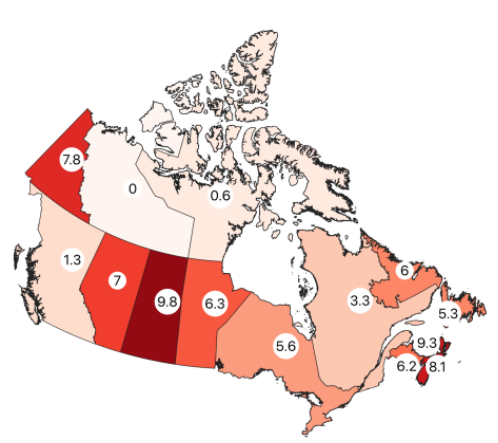

S2

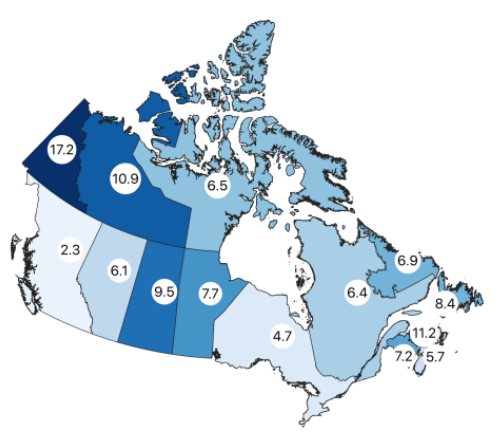

S3

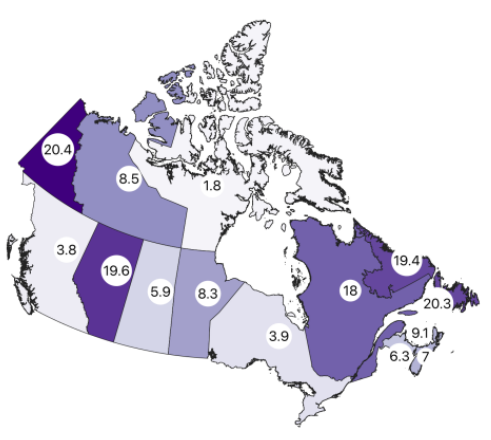

S4

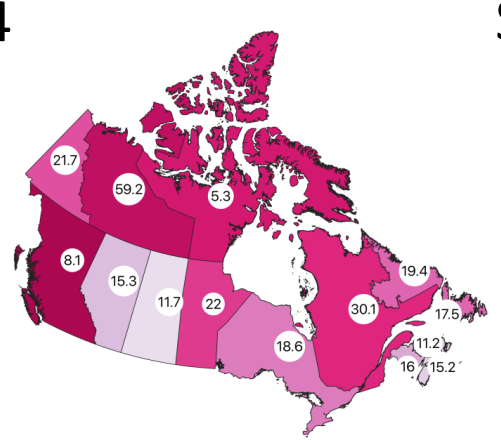

S5

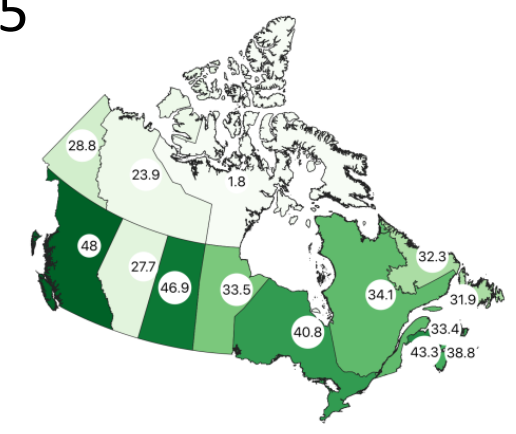

$\mathrm{SH}, \mathrm{SX}$

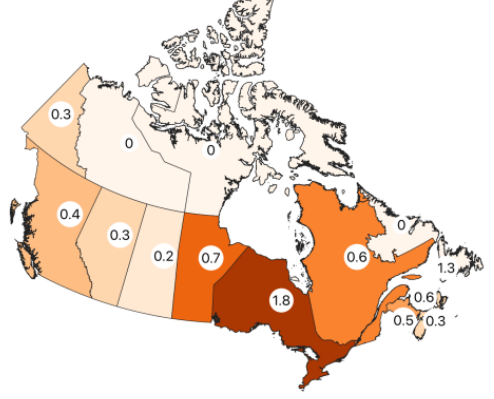

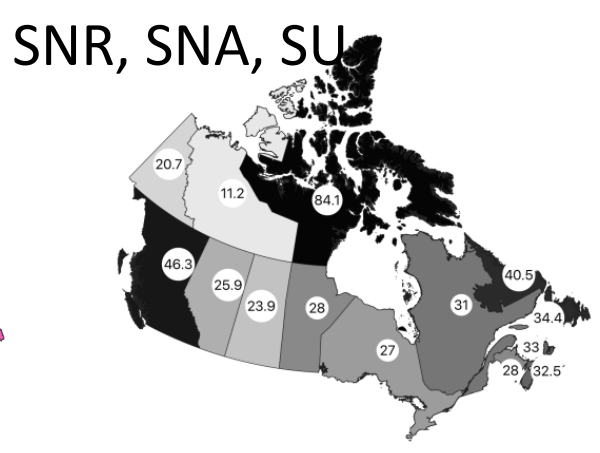

(c) The Author(s) or their Institution(s) 

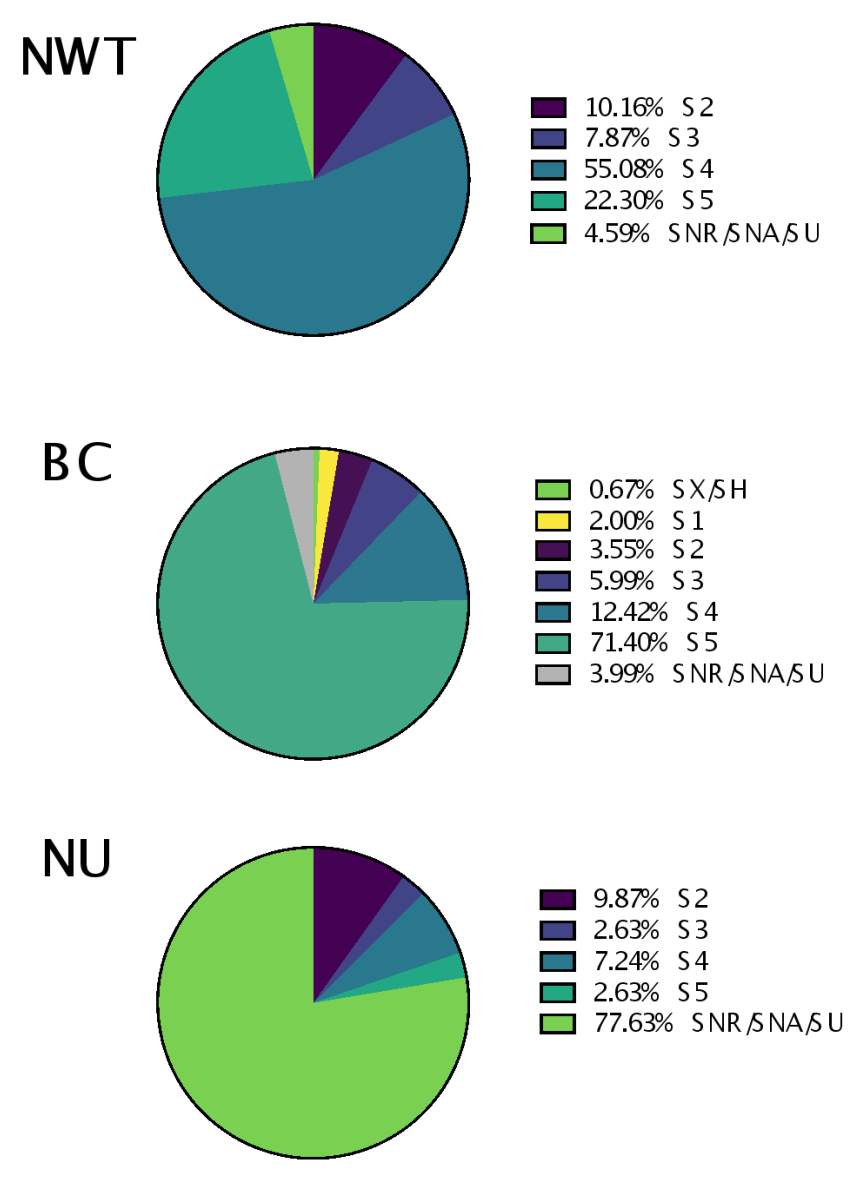
a

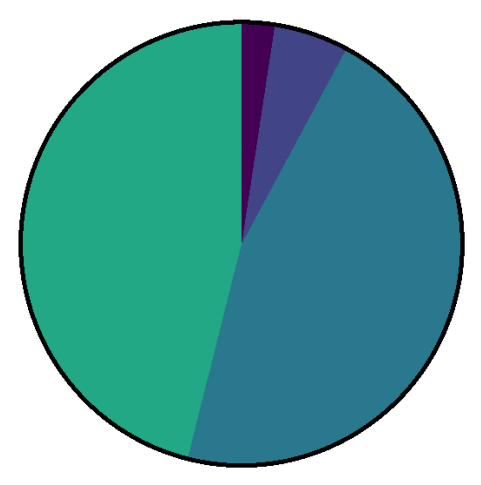

C

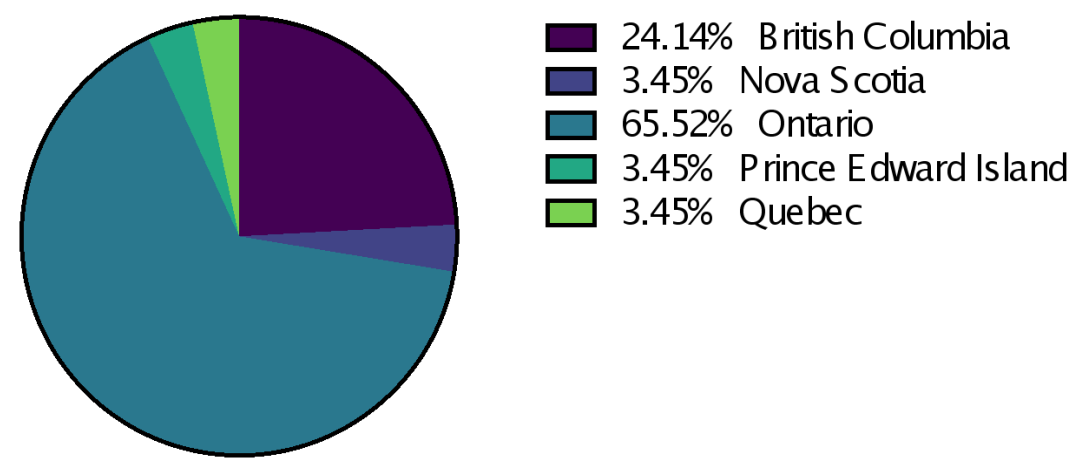

b

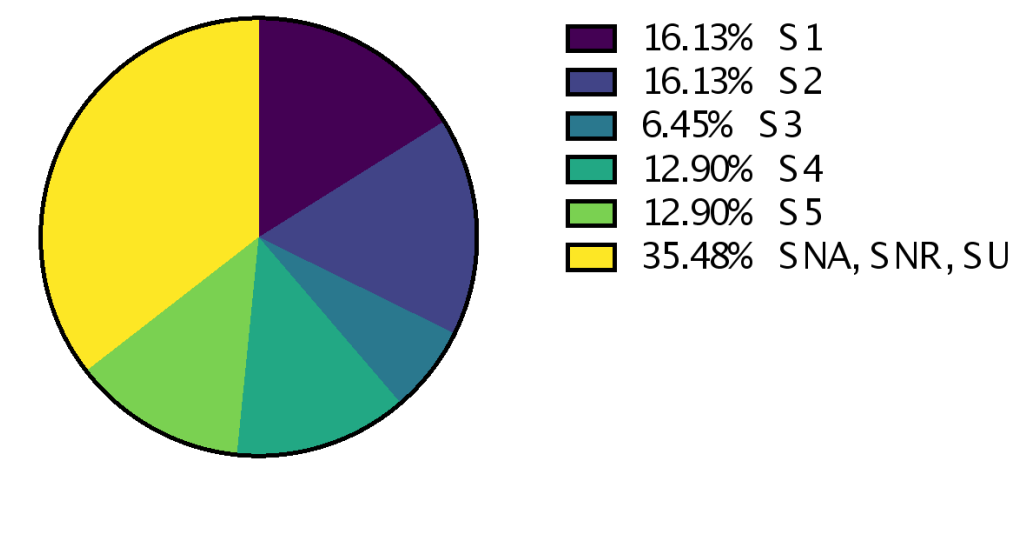

